\title{
天井面下の熱気流温度に基づく火点検知手法に関する実験的研究 \\ AN EXPERIMENTAL STUDY ON PREDICTING METHOD OF FIRE LOCATION BASED ON CEILING JET TEMPERATURE UNDER UNCONFINED CEILING
}

\author{
新田 孝太郎*, 山口 純一**, 岡 泰 資***, 村岡 宏**** \\ Kotaro NITTA, Jun-ichi YAMAGUCHI, Yasushi OKA \\ and KO MURAOKA
}

\begin{abstract}
There is a possibility that an unexpected long time is required to identify the fire occurrence location in a room with obstruction of visibility by the smoke, distributed exhibit cases and production machines, such as in the factory where the floor space is extremely large and in the merchandize shops where various goods are exhibited. It is believed that identification of the fire occurrence location in the early stage of the fire makes the fire fighting more effective. For this purpose, a new algorithm for estimating the fire occurrence location and the heat release rate, is developed by transforming Alpert's equation, namely with the aid of the temperature decreasing property of the ceiling jet formed under the unconfined ceiling in a quasi-steady state. Compared with the experimental results, this proposed method is found sensitive to the number and installation interval of sensors used for the calculation and fluctuation of temperature data.
\end{abstract}

\section{Keywords : CeilingJet, Fire Location, Unconfined Ceiling, Heat Release Rate 天井流, 火点, 無限天井, 発熱速度}

1. はじめに

建築物の火災安全対策の主な目的は, 人命安全の確保, 財産の保 護, 消防活動の支援である ${ }^{1)}$ 。このうちの消防活動の支援に着目す ると, 通常消防隊は建物外部から火点にアクセスし, 状況に応じて 消火・救助活動を行なう。消防活動を安全かつ的確に行うには, 活 動执点の確保や消防設備の効果的な利用に加えて, 現在の火点の位 置やその状況といった火災情報の提供も重要である。特に室の床面 積が数干 $\mathrm{m}^{2}$ 以上にもなる大規模物販店舗や製造工場等では, 商品陳 列棚や製作機械等の過密配置による見通しへの障害や火炎により発 生した煙による見通し距離の低下により, 消防隊の火点へのアクセ スの遅れによる被害の拡大や，消防隊自身が危険に曝される可能性 が高まることも考えられる。

現在，消防隊に火災情報を提供するものとして自動火災報知シス テムがある。自動火災報知システムは天井面下に設置された感知器 からの信号をもとに出火区域を把握するものであるが，詳細な火点 位置や時々刻々と変化する火災の進展状況を分析する機能までは備 えていない。そこで, 感知器等から得られる情報を分析することで 火点位置や火源規模を特定し，リアルタイムでその情報を伝達でき れば，火災による被害を扡大させず局所化できると考えられる。
本研究は, 火災時における火点検知に関わる基嗼的研究として, 水平で平らな天井下に配置された複数の感知器等の温度センサから の情報に基づく火点検知手法を考案するとともに, 火炎が天井に接 炎する以前の火災の熱気流性状を再現した燃焼実験結果を用いて, 火点検知手法の妥当性の検討を行うことを目的とする。

\section{2. 火点位贯検知手法}

平面的に大きな空間で火災が発生した場合，火災初期における天 井下の熱気流 (以降, 天井流と言う。) の温度性状は, 周壁の影響を 受けることのない無限天井下のそれに近い性状を示すと考えられる。 そこで, 本研究では無限天井下における天井流の温度減衰式をもと にした火点検知手法を提案する。

\section{1 基本的な考え方}

天井流の温度は，火源中心軸からある任意の位置までの距離（以 降, 流動距離と言う。）に応じて诚衰する。水平な天井面に設置され た複数の温度センサと火源との関係を見た場合, 火源規模の大小に かかわらず，ある時刻における発熱速度，火源から天井までの高さ は何れの温度センサに対しても同条件である。そのため, 各温度セ
* 横浜国立大学大学院環境情報学府

*** (侏)大林組技術研究所工修

*** 横浜国立大学大学院環境情報学研究院 博士 (工学)

**** 侏大林組技術研究所 博士 (工学)
Yokohama National University

Technical Research Institute, Obayashi Corporation, M. Eng

Yokohama National University, Dr. Eng.

Technical Research Institute, Obayashi Corporation, Dr. Eng. 
ンサの近傍における天井流温度は流動距離のみに依存することにな る。そこで複数の温度センサから得られた温度情報とそれぞれの流 動距離の関係を相互に比較することにより，火点位置を推測するの が基本的な考え方である。これは，地震発生直後に震源に近い稓測 点で得られた地震波データ（P波もしくは $\mathrm{S}$ 波）から，震源情報（震 源地，地震の規模）を推定するのと同様の考え方である。

\section{2 本研究で用いた火点検知方法}

実際に天井下に温度センサを設圆することを想定した場合，温度 センサを格子状に配㯰することが多いであろう。しかし，本研究で は不具合等によって部分的に使用できない温度センサが生じる可能 性を考虑して，温度センサがランダムに設置された場合に対応した 火点検知手法を検討することとした。

\section{2.1 天井流の基本性状}

Alpert ${ }^{2)}$ は次元解析および水平な無限天井空間において火源から 天井までの高さ 4.6〜 15.5m, 発熱速度 0.67〜98MW の火源を用いた 実大規模の実験を行い，天井面下の熱気流の温度について

$$
\Delta T=5.38 \frac{\dot{Q}_{f}^{2 / 3} / H^{5 / 3}}{(r / H)^{2 / 3}} \quad\left(0.18<\frac{r}{H}<4\right)
$$

の関係式を提案した。ここで $\Delta T$ は位置 $r$ における熱気流の周囲空 気温度からの温度上昇 $[\mathrm{K}], r$ は火源中心軸からの流動距離 $[\mathrm{m}], H$ は

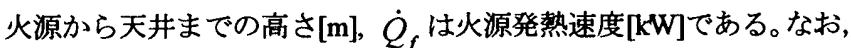
$r / H \leqq 0.18$ の範囲はよどみ領域と呼ばれており，本研究の対象外と した。

また, 式(1)を火災安全工学の分野でよく使用される無次元発熱速 度 $Q^{*}[-]$

$$
Q^{*}=\frac{\dot{Q}_{f}}{\rho_{\infty} C_{P} T_{\infty} g^{1 / 2} H^{5 / 2}}
$$

および無次元温度上昇 $\Delta T^{*}[-]$

$$
\Delta T^{*}=\frac{\left(\Delta T / T_{\infty}\right)}{Q^{* 2 / 3}}
$$

を用いて整理すると式(4)のようになる。

$$
\Delta T^{*}=5.38 \frac{\left(\rho_{\infty} C_{p} T_{\infty} g^{1 / 2}\right)^{2 / 3}}{T_{\infty}}\left(\frac{r}{H}\right)^{-2 / 3} \quad\left(0.18<\frac{r}{H}<4\right)
$$

ここで, $\rho_{\infty}$ は空気の密度 $\left[\mathrm{kg} / \mathrm{m}^{3}\right], C_{p}$ は空気の比熱 $[\mathrm{kJ} /(\mathrm{kg} \cdot \mathrm{K})], T_{\infty}$ は 周囲空気の温度 $[\mathrm{K}], \mathrm{g}$ は重力加速度 $\left[\mathrm{m} / \mathrm{s}^{2}\right]$ である。なお, 以下では $\boldsymbol{r} / H$ を無次元流動距離[-]と呼ぶこととする。

\section{2.2 天井流温度と減衰距離の関係}

図 1 は 3 つの温度センサからの温度情報を基に火点を特定する方 法を説明するための概念図である。ここで $\left(x_{1}, y_{1}\right),\left(x_{2} y_{2}\right),\left(x_{3}, y_{3}\right)$ は, それぞれ温度センサ $1,2,3$ の設置座標, $\Delta T_{1}, \Delta T_{20} \Delta T_{3}$ はそれぞれ温 度センサ $1,2,3$ の温度上昇, $r_{1}, r_{2}, r_{3}$ は火火災プルームが水平天井に 衝突した位置 (火点中心座標 $\left(x_{f}, y_{f}\right)$ ) から温度センサ 1, 2, 3 までの距 離である。なお, 本研究では火源から天井までの高さ $H$ の代わりに,

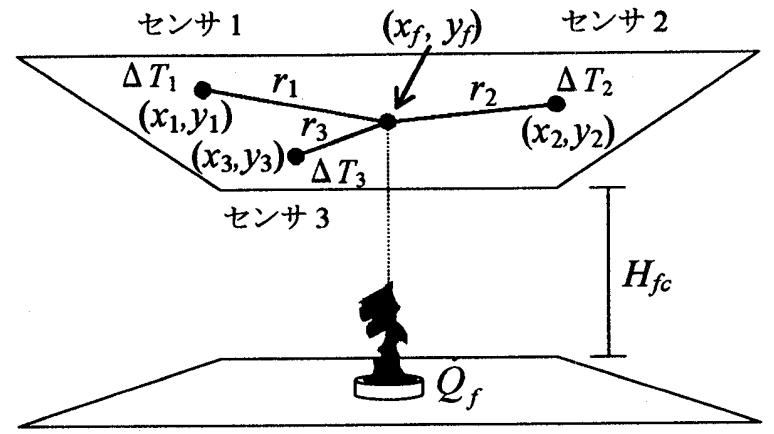

図 1 火点位置検知の概念図

火皿下端から天井までの高さ $H_{f c}$ を用いている。

天井流が生じると, 各温度センサからの温度情報が逐次得られる。 天井流の温度上昇は, 式(1)より, $\dot{Q}_{f}, H_{f o} r$ を変数とした累乗の関数 で表せる。しかし, 天井材の種類, 表面状態, 形状等によっても天 井流の温度性状が変わることが予想されるため，本研究においては 式(1)を幾分一般化して，下式のように表せると考えた。

$$
\Delta T=k \dot{Q}_{f}^{\alpha} H_{f c}^{\beta} r^{\gamma} \quad\left(a<r / H_{f c}<b\right)
$$

ここで， $k ， \alpha ， \beta$ 及び $\gamma$ は温度センサが設置された天井材の種類, 表面状態，形状等によって変化する定数である。また， $a$ および $b$ は式(5)の無次元流動距離に対する適用範囲の下限值および上限値 である。

温度センサ 1 の温度 $\Delta T_{1}$ は, 式(5)より，

$$
\Delta T_{1}=k \dot{Q}_{f}^{\alpha} H_{f c}^{\beta} r_{1}^{\gamma}
$$

と表せる。火点位置は不明であるが, 火点中心座標 $\left(x_{f}, y_{f}\right)$ から温度 センサ $1\left(x_{1}, y_{1}\right)$ までの距離 $r_{1}$ は,

$$
r_{1}=\sqrt{\left(x_{1}-x_{f}\right)^{2}+\left(y_{1}-y_{f}\right)^{2}}
$$

となる。これを式(6)に再代入すると，

$$
\Delta T_{1}=k \dot{Q}_{f}^{\alpha} H_{f c}^{\beta}\left\{\sqrt{\left(x_{1}-x_{f}\right)^{2}+\left(y_{1}-y_{f}\right)^{2}}\right\}^{y}
$$

を得る。また，温度センサ 2 の温度上昇 $\Delta T_{2}$ は，同様に

$$
\Delta T_{2}=k \dot{Q}_{f}^{\alpha} H_{f c}^{\beta}\left\{\sqrt{\left(x_{2}-x_{f}\right)^{2}+\left(y_{2}-y_{f}\right)^{2}}\right\}
$$

となる。

天井面に設㯰される温度センサの個数は，できる限り少ない方が 経済的に有利であるため，限られた温度情報の中で検知精度を向上 させるには， $\dot{Q}_{f} や H_{f c}$ などの末知数はない方が好ましい。そこで本 研究では, 式(8)と式(9)の比をとり，火点中心座標である $x_{f}$ および $y_{f}$ のみを末知数とした

$$
\frac{\Delta T_{1}}{\Delta T_{2}}=\left\{\frac{\sqrt{\left(x_{1}-x_{f}\right)^{2}+\left(y_{1}-y_{f}\right)^{2}}}{\sqrt{\left(x_{2}-x_{f}\right)^{2}+\left(y_{2}-y_{f}\right)^{2}}}\right\}^{\gamma}
$$

なる関係式を用いることとした。

同様に, 温度センサ 2 の温度上昇 $\Delta T_{2}$ と温度センサ 3 の温度上昇 $\Delta T_{3}$ の比をとると，

$$
\frac{\Delta T_{2}}{\Delta T_{3}}=\left\{\frac{\sqrt{\left(x_{2}-x_{f}\right)^{2}+\left(y_{2}-y_{f}\right)^{2}}}{\sqrt{\left(x_{3}-x_{f}\right)^{2}+\left(y_{3}-y_{f}\right)^{2}}}\right\}^{\gamma}
$$


となる。従って，式(10)および式(11)を同時に満足するような火点座 標 $\left(x_{f}, y_{f}\right)$ を検索すれば， $\dot{Q}_{f}$ や $H_{f c}$ が未知であっても火点位置を特定 できる。なお，火点位置を検知するには最低 3 つの温度センサから 得られる温度情報と設置位置座標が必要であると言える ${ }^{\text {1)。 }}$

\subsection{3 走查座檡を用いる方法}

実際には，式(10)および式(11)を同時に満足するような火点座標を ピンポイントで特定することは難しい。そこで, 式(10)および式(11) における火点座標 $\left(x_{f}, y_{f}\right)$ の代わりに走查用の座標 $\left(x_{s} y_{s}\right)$ を用い, これ を移動させながら式(10)および式(11)を同時に満足する座標を検索 するのが実用的な方法である。

図 2 は，火点の走查方法を説明するために走查範囲を $n \times m$ 個の グリッドに分割した例で，図 1 に示した火点中心座標および温度セ ンサ座標を平面的に示している。なお， $x$ 軸方向のグリッド間隔は $d x, y$ 軸方向のグリッド間隔は $d y$ である。操作方法は以下の通り。

先ず各温度センサから温度（ $\Delta T_{1}, \Delta T_{2}$ およ゙ $\left.\Delta T_{3}\right)$ を得る。つ ぎに走査座標 $\left(x_{s}, y_{s}\right)$ を走査原点 $\left(x_{0}, y_{0}\right)$ から順次, $d x$ もしくは $d y$ ずつ 移動する。その都度, 式(10)および式(11)を同時に満足するか否かを 判定し，両式を同時に満足した時点で走査を終了し，その時の走查 座標を火点とする。

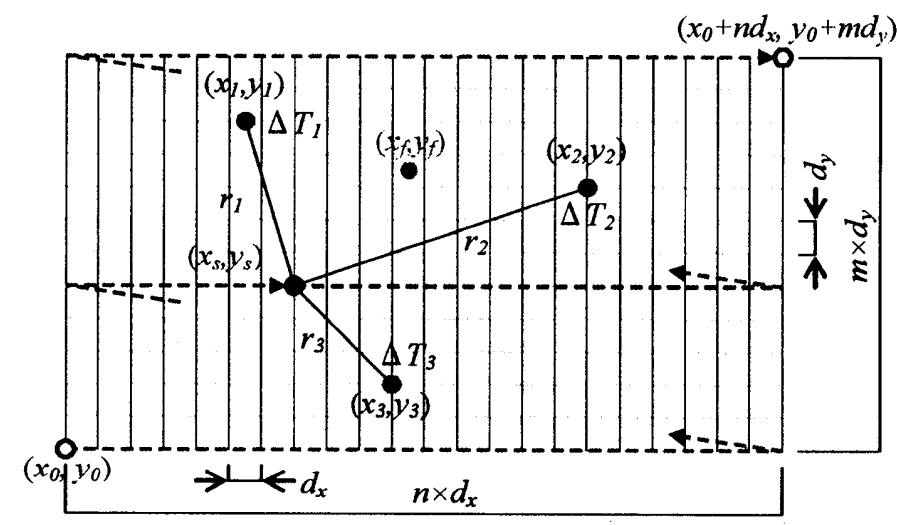

図 2 火点の走査方法

\subsection{4 残差 $R$ の最小值から推定する方法}

前述した火点位置の推定方法は, 式(10)および式(11)もしくは両式 の基となる式(5)と，実際の天井流の温度減衰が一致していることを 前提としている。しかし，両者がどのような状況においても常に一 致するとは限らない。そのため本研究では，式(10)および式(11)それ ぞれについて右辺と左辺の差をとり，両者の絶対値の総和を残差 $R$ とし,この值が最小值を示す走査座標を火点と判断することとした。 ここで残差 $R$ は, 式(10)および式(11)から

$$
\begin{aligned}
R\left(x_{s}, y_{s}\right) & =\left|\frac{\Delta T_{1}}{\Delta T_{2}}-\left\{\frac{\sqrt{\left(x_{1}-x_{s}\right)^{2}+\left(y_{1}-y_{s}\right)^{2}}}{\sqrt{\left(x_{2}-x_{s}\right)^{2}+\left(y_{2}-y_{s}\right)^{2}}}\right\}^{\gamma}\right| \\
& +\left|\frac{\Delta T_{2}}{\Delta T_{3}}-\left\{\frac{\sqrt{\left(x_{2}-x_{s}\right)^{2}+\left(y_{2}-y_{s}\right)^{2}}}{\sqrt{\left(x_{3}-x_{s}\right)^{2}+\left(y_{3}-y_{s}\right)^{2}}}\right\}\right|
\end{aligned}
$$

となる。なお, 式(12)では, 式(10)および式(11)における火点 $\left(x_{f}, y_{f}\right)$ を走查座標 $\left(x_{s} y_{s}\right)$ に変更して表現している。

\section{3 实験概要}

\section{1 実験装置}

実験に使用した模擬無限天井の大きさは $8.5 \mathrm{~m}(\mathrm{~W}) \times 5.8 \mathrm{~m}(\mathrm{~L})$ で，仮 想床から $3 \mathrm{~m}$ の高さに水平に設置した。この模擬無限天井は厚さ $12 \mathrm{~mm}$ の合板下地に9.5mmの石亳ボードで構成されている。本実験で は天井流の基本的な性状を把握することを目的としていることから， 実験装置の側面に壁は設置していない。またこの実験装置は $28.8 \mathrm{~m}(\mathrm{~W}) \times 17.1 \mathrm{~m}(\mathrm{~L}) \times 11.1 \mathrm{~m}(\mathrm{H})$ の吹抜空間の中に設置した。

\section{2 湘定項目}

1)温度

図3に温度の測定位膡を示したように，素線径 $0.32 \mathrm{~mm}$ のK型熱電 対を天井面から鉛直下方に $5 \mathrm{~cm}$ 注2 2 の高さの水平面上に, 天井の中心 を起点として $1 \mathrm{~m}$ 間隔で格子状に45点設置し, データロガーを介して 1秒間隔で温度を測定した。

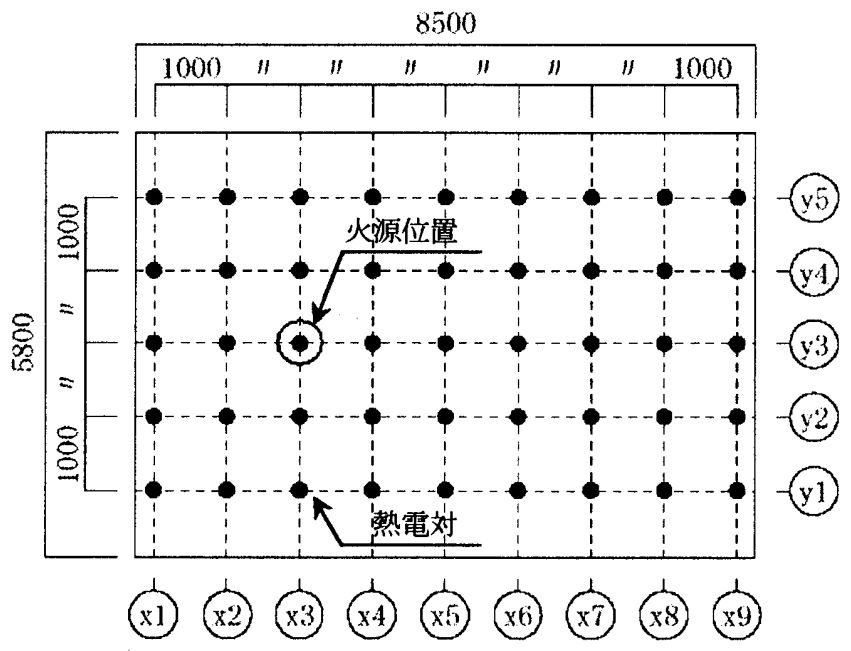

図 3 熱電対配直図（平面図）

单位: mm

\section{2)然料の重量減少速度}

火源の発熱速度を把握するために燃料の重量减少を重量計（ザル トリウス社製，LP64401S）で測定した。秤量天板の保護板として厚 さ0.6m $\times 0.6 \mathrm{~m} \times 0.05 \mathrm{~m}$ のケイ酸カルシウム板を設置して，その上に 燃料を投入するための円形火皿を設置した。その結果，円形火皿の 下端（ケイ酸カルシウム板の上面）は（仮想）休面から $19 \mathrm{~cm} の$ 高さ に位㯰している。

火源発熱速度は燃料の重量堿少速度とその理論発熱量から算出し た。なお，本研究で燃料として使用したメタノールの理論発熱量は $19,830 \mathrm{~kJ} / \mathrm{kg}$ である。

\section{3 実験条件}

表1に火皿下端から天井までの高さおよび火源規模を変化させて 実施した12ケースの実験条件を示す。なお，火源中心は何れのケー スにおいても図3の $(\mathrm{x}, \mathrm{y})=(3,3)$ の位㯰とした。 


\section{1)天井高さ}

高さ調節機構の付いた仮設ステージ上に火源を設置することによ って, 火皿下端から天井までの高さを $2.81 \mathrm{~m}, 2.17 \mathrm{~m}, 1.56 \mathrm{~m}$ よび $0.94 \mathrm{~m}$ の段階に変化させた。

\section{2) 火源発熱速度}

円形火皿の大きさを変えることで火源の発熱速度を調節した。燃 料火四はいずれも哚さ $4 \mathrm{~cm}$ のものを使用し，直径 $0.2 \mathrm{~m}, 0.3 \mathrm{~m}, 0.4 \mathrm{~m}$ お よび0.6mの4種類の中から, 模擬無限天井に接炎しないように天井 高さに応じて3種類を選択して使用した。

表 1 実験条件

\begin{tabular}{|c|c|c|c|}
\hline No & $\begin{array}{c}\text { 天井高さ } \\
H_{f c}[\mathrm{~m}]\end{array}$ & $\begin{array}{c}\text { 火源直径 } \\
\text { [m] }\end{array}$ & 温度測定範囲 \\
\hline$\overline{1}$ & \multirow{3}{*}{2.81} & $\phi 0.2$ & \multirow{3}{*}{$0.36 \leqq r / H_{f c} \leqq 2.3$} \\
\hline 2 & & $\phi 0.4$ & \\
\hline 3 & & $\phi 0.6$ & \\
\hline 4 & \multirow{3}{*}{ 2. 17} & $\phi 0.2$ & \multirow{3}{*}{$0.46 \leqq r / H_{f c} \leqq 2.9$} \\
\hline 5 & & $\phi 0.4$ & \\
\hline 6 & & $\phi 0.6$ & \\
\hline 7 & \multirow{3}{*}{1.56} & $\phi 0.2$ & \multirow{3}{*}{$0.64 \leqq r / H_{f c} \leqq 4.1$} \\
\hline 8 & & $\phi 0.4$ & \\
\hline 9 & & $\phi 0.6$ & \\
\hline 10 & \multirow{3}{*}{0.94} & $\phi 0.2$ & \multirow{3}{*}{$1.1 \leqq r / H_{f c} \leqq 6.7$} \\
\hline 11 & & $\phi 0.3$ & \\
\hline 12 & & $\phi 0.4$ & \\
\hline
\end{tabular}

\section{4. 实験結果}

\section{1 火源発熱速度と各位盢の温度}

図4に実験条件No.1, 2,3および11（火孟径は順に0.2, 0.4, 0.6, 0.3m) における重量減少速度から算出した火源発熱速度の時間変化を示す。

これより, 何れの条件でも発熱速度は, 着火直後に急激に上昇し， それ以降は緩やかな上昇傾向にあるが準定常的に燃焼しているとい える。なお，それぞれの実験条件における200～300秒の平均発熱速 度は火皿径 $0.2 \mathrm{~m}$ では $8.3 \mathrm{~kW}$ ，火皿径 $0.3 \mathrm{~m}$ では $20 \mathrm{~kW}$ ，火皿径 $0.4 \mathrm{~m}$ では $40 \mathrm{~kW}$ ，火血径 $0.6 \mathrm{~m}$ では93kWであった。

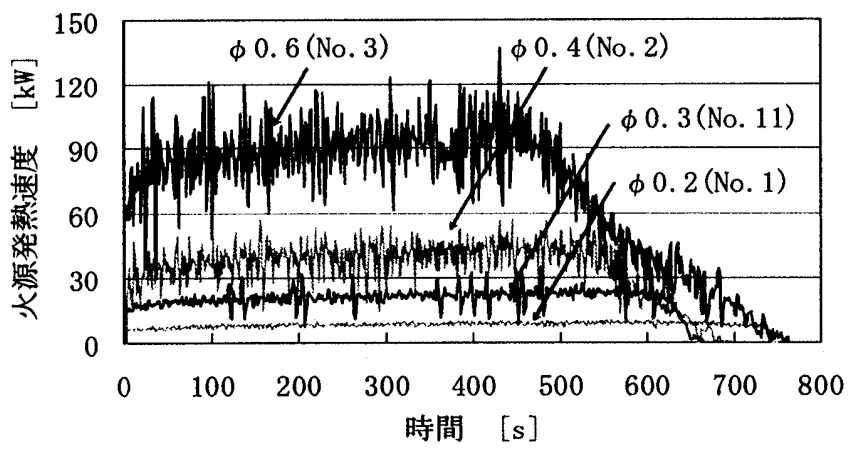

図 4 火源発熱速度の時間変化

図5は，実験条件No.2（ $H_{\hat{k}}=2.81 \mathrm{~m}$ ，火血径 $0.4 \mathrm{~m} ）$ における，測定 点座標 $(4,3),(5,3),(6,3),(7,3),(8,3) お よ ひ ゙(9,3)$ の井流温度の時間 変化を示したものである。
図5より，各位置の温度は熱気流の波に応答し，細かく振動してい ることが分かる。しかし，大きな傾向としては火点 $(3,3) に$ に近い位置 の天井流温度は高く，火点から遠ざかるに谜い温度は低くなる。ま た, 測定点が火点から遠ざかるに従い着火後の温度上昇の立ち上が りが遅れている。この時間差は着火直後の熱気流が各測定点に到達 するまでに要する時間であり, 出火直後の火点検知精度に大きな影 響を及ぼす可能性がある。

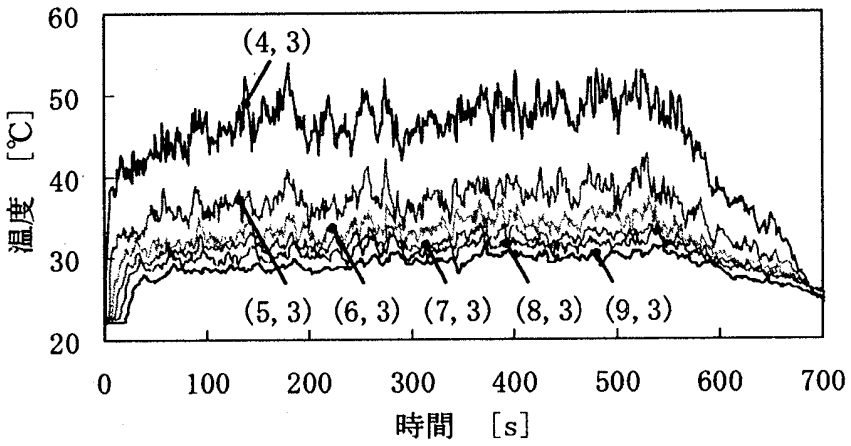

図 5 各測定点における温度の時間変化

図6に，実験条件No.2で得られた温度データ（淮定常的に燃焼して いる燃焼開始後 120 秒における瞬間値)を基に作成した等温度線図を 示す。ここでx軸の数值は各測定点の $x$ 座標を, $y$ 軸の数值は各測定点 の座標を意味し，座標間隔は軸, $\boldsymbol{y}$ 軸ともに1mである。

これより天井流は火点(3,3)を中心とする同心円状に拡がることが 分かる。このような緻密な等温度線図が得られれば，特殊な手法を 用いることなく容易に火点を推定できる。

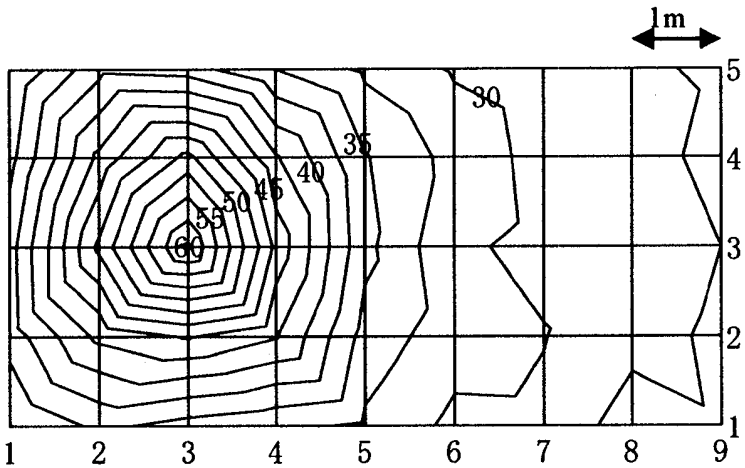

図 6 全測定点の 120 秒時点における温度を基に 作図した等温度線図（等温線間隔 $2.5\left[{ }^{\circ} \mathrm{C}\right]$ )

一方，図7は，図6で用いた温度のうち座標 $(2,1) ，(5,1),(2,4)$ お び(5,4)の4点の温度情報を基に作成した等温度線図である。

図7より，4点の温度情報を基に作図した等温度線図からは火点を 推定することは難しいことが分かる。実際の建築空間では火炎感知 器は7〜9m間隔に不等間隔に配置されるのが一般的であり，図6のよ うな詳細な分布を得ることは期待できない。そのため，先に示した 火点位置検知手法が有効になるのである。 


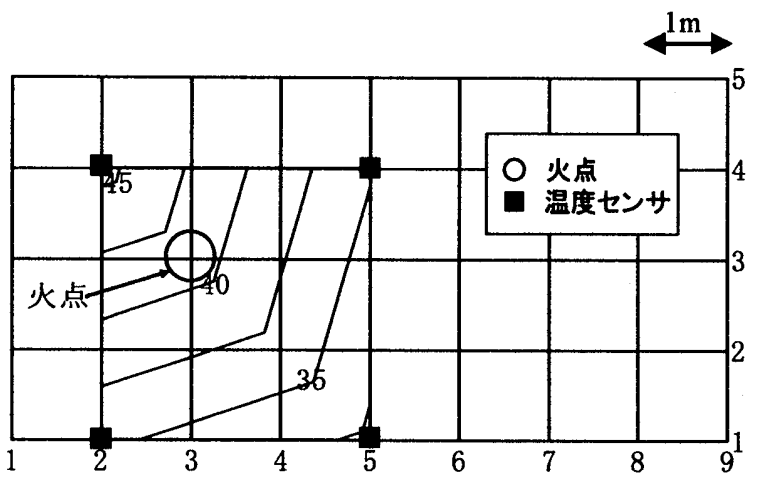

図 $7(2,1),(5,1),(2,4),(5,4)$ の 120 秒時点における温度を 基に作図した等温度線図（等温線間隔 $2.5\left[{ }^{\circ} \mathrm{C}\right]$ ）

\section{2 天井流の温度娍表性状}

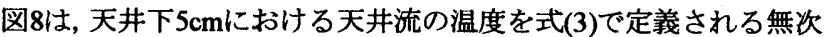
元温度上昇 $\Delta T^{*}$ に変換し, 無次元流動距離 $r / H_{f c}$ に対してプロットし た結果である。なお図8に用いた温度は, 各実験条件において発熱速 度が淮定常状態である燃焼開始後200〜300秒の平均值を用いた。

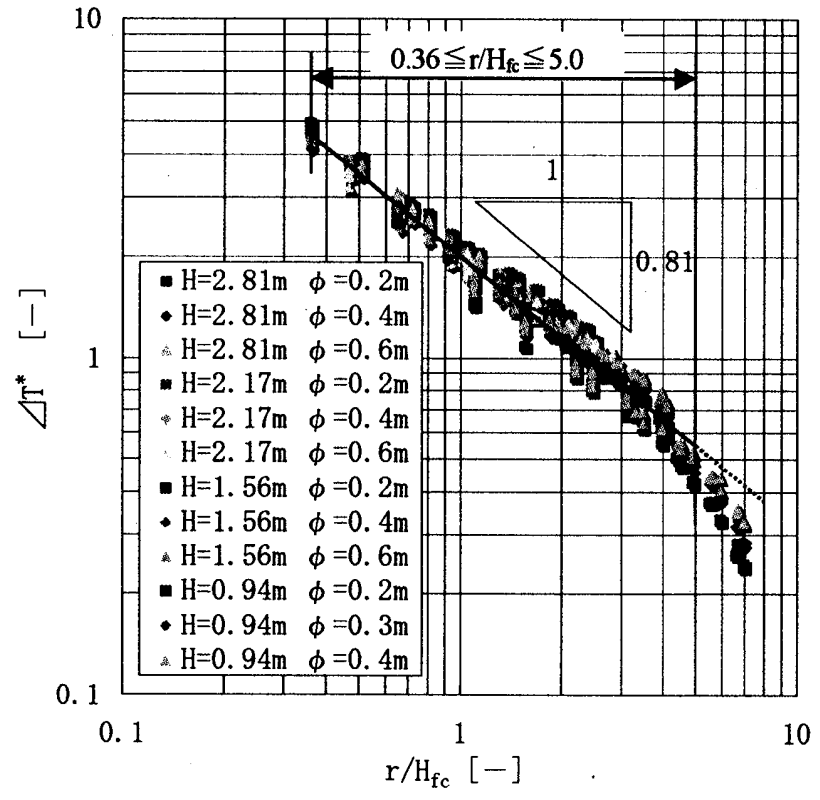

図 8 無次元温度上昇の減衰性状

図8より， $0.36 \leq r / H_{f c} \leq 5.0$ の範囲にあっては，無次元温度上 昇 $\Delta T^{*}$ は, 無次元流動距離 $r / H_{\mathfrak{k}}$ に対して概ね一定の減衰率を保持し て温度が低下することが分かる。また，前述の範囲において無次元 温度上昇 $\Delta T^{*}$ を無次元流動距離 $r / H_{k \varepsilon}$ に対して回㷌した結果,

$$
\Delta T^{*}=2.03\left(r / H_{f c}\right)^{-0.81}
$$

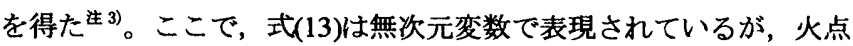
検知に使用する場合は有次元で表現した方が扱いやすい。そこで式 (13)に式(2)と式(3)を代入して，温度上昇 $\Delta T$ に対して整理すると式 (14)が得られる。

$$
\begin{gathered}
\Delta T=k \dot{Q}_{f}^{0.67} H_{f c}^{(0.81-5 / 3)} r^{-0.81} \\
\text { ただし } \left.k=\frac{2.03 T_{\infty}}{\left(C_{p} \rho_{\infty} T_{\infty} g^{1 / 2}\right)^{2 / 3}}\right)
\end{gathered}
$$

なお, 後述の火点位固検知結果は, 式(12)の $\gamma$ として, 実験から得 られたべき乗数 $($-0.81)を用いている。

\section{5. 火点位贯検知に関する検砷}

\section{1 温度のサンプリング方法と検知精度の関係}

図 9 は, 実験条件 No.2 において, 座標 $(5,3)$ における着火後 120 150 秒間の温度履歴を示したものである。火点検知に用いる温度デ 一タとしては, 生データ(図中○)をそのまま使用する方法と, 破線 および実線で示したように生データをある時間蓄積し，その時間の 平均値を使用する方法が考えられる。図 9 から分かるように生デー 夕は小刻みに変動しており, 今回検証するような準定常火源では, できるだけ平均時間を長くした方が検知精度は向上すると思われる。 しかし, 平均時間が長くなると非定常火源や火点の移動といった急 に火災性状が変化する場合に対応できなくなる恐れがあるため，平 均時間はある程度の検知精度が得られる範囲内で短い方がよいと考 えられる。

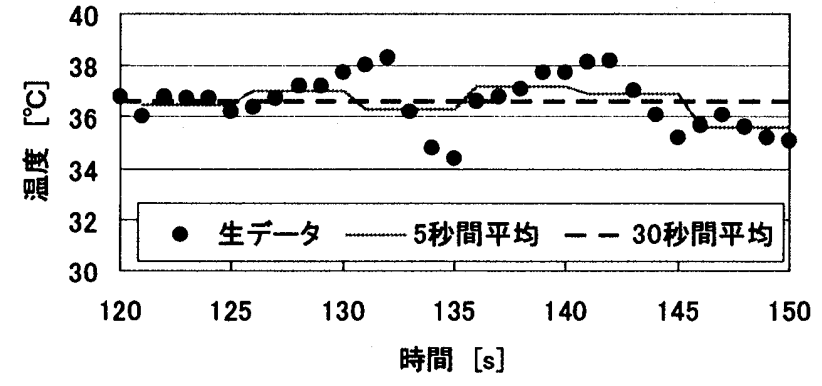

図 9 測定温度のサンプリング方法

図10は，実験No.2において座標（1,1)，(5,1)および $(5,5)$ の温度セ ンサから1秒毎に得られる温度情報を基に火点を推定し,その結果を 座標上に1秒毎に示した結果である。なお, 各温度センサの温度上昇 が認められた着火5秒後から火点検知が始まっている。また図10には 実際の火点座標 $(3,3)$ と検知に用いた温度センサの座標も合わせて 表示した。

図 10 より,検知した火点は着火後 5 秒から 120 秒までの間は大き く変動し火点を特定するには至ってない。しかし，121 秒以降では 検知された火点は実際の火点位直に近いことが分かる。

実際の火点と推定した火点との距離を誤差とし, 検知誤差を定量 的に把握するために式(15)を用いて平均誤差 $\bar{E}$ を算出した。

$$
\bar{E}=\frac{\sum_{i=1}^{N} \sqrt{\left(x_{f(s)}^{i}-x_{f}\right)^{2}+\left(y_{f(s)}^{i}-y_{f}\right)^{2}}}{N}
$$

ここで, $N$ は総検知回数, $x_{f(s)}^{i}, y_{f(s)}^{i}$ はそれぞれ検知開始から $i$ 回目に検知された火点の $x$ 座標, $y$ 座標である。式(15)に従い図 10 に示した検知結果の平均誤差を算出したところ，5１20秒の平均誤 差は $1.0 \mathrm{~m}, 121 \sim 210$ 秒の平均誤差は $0.47 \mathrm{~m}, 5 \sim 210$ 秒の平均誤差 は $0.76 \mathrm{~m}$ であった。 


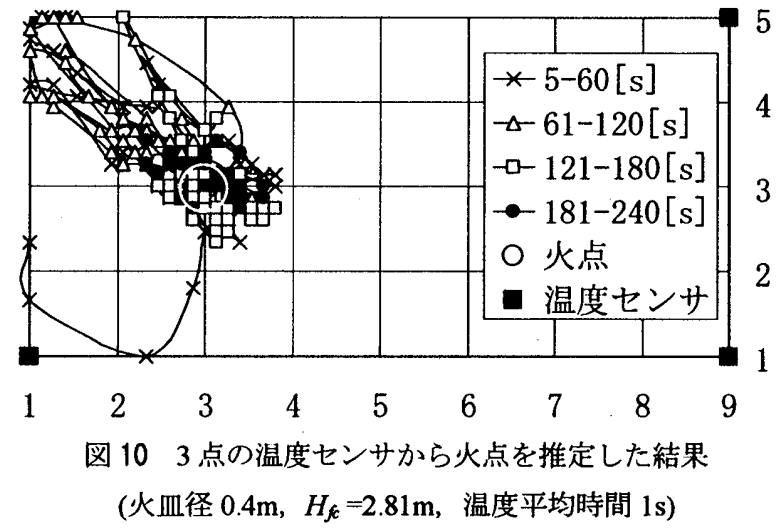

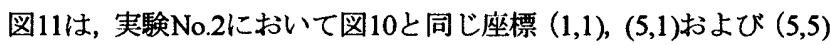
の温度センサから得られる温度情報を $15 \mathrm{~s} ， 30 \mathrm{~s} ， 60 \mathrm{~s}$ とある時間蓄積 し (以後, 温度平均時間と言う。), その間の平均值を用いて火点検 知した結果を示した結果である。なお，温度平均時間が $15 \mathrm{~s}$ の場合， 着火から15秒間は温度情報を蓄積するため, 検知を開始するのは 15 秒以降となる。同様に温度平均時間が $30 \mathrm{~s} の$ 場合は30秒以降，60sの 場合は60秒以降に検知を開始している。またそれぞれの検知結果は, 検知が開始された時点から着火後 210 秒までを示している。

図 11 より，生の温度データを用いた図 10 の場合と比較すると何 れの温度平均時間の場合においても格段に検知精度が向上すること がわかる。これは図 9 に示したように, 1 秒每に得られる温度のゆ らぎの影響が，平均温度を用いたことで緩和されたからである。な お,この時の $60 \sim 210$ 秒の平均誤差は温度平均時間が $15 \mathrm{~s}$ では $0.48 \mathrm{~m}$, $30 \mathrm{~s}$ では $0.44 \mathrm{~m}, 60 \mathrm{~s}$ では $0.40 \mathrm{~m}$ であった。以上より，準定常状態の 火源においては温度平均時閒を長くすると検知精度は向上するとい える。

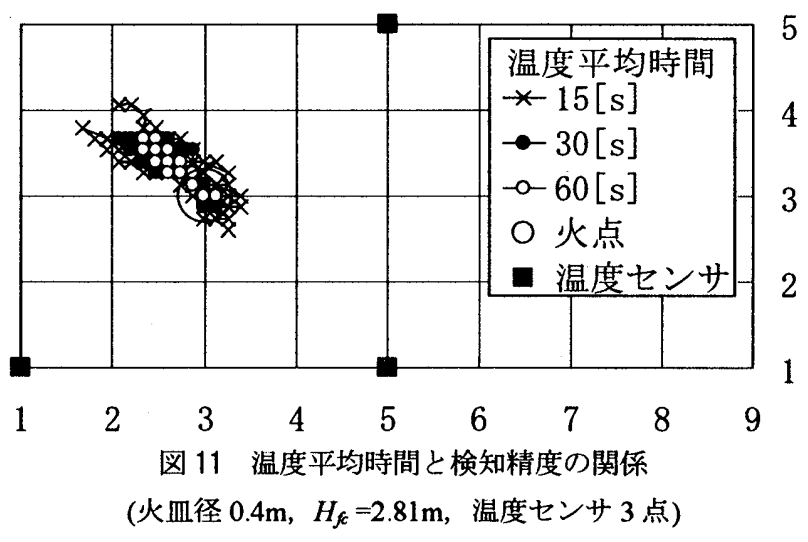

\section{2 温度センサ設置間隔と検知精度の関係}

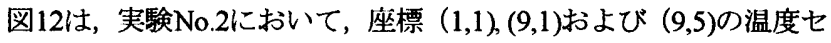
ンサから1秒毎に得られる温度情報を30秒間蓄積し，その30秒間の平 均温度を基に火点を推定した結果である。

図12より，図11の温度センサ設置間隔が小さい場合と比較して検 知精度が大幅に低下していることが分かる。特に30１80秒の検知精 度の悪化が著しい。一方で, 181秒以降の検知精度は比較的良いこと が分かる。この検知精度の違いは, 火点から遠い温度センサ $((9,1)$ もしくは $(9,5)$ ) までの天井流の到達遅れ時間の影響が小さくなった ことが原因と考えられる。また30〜210秒の平均誤差は1.81mであっ た。これより温度センサの設膡間隔を大きくすると検知精度が大き く低下するため，実用化に際しては必要な検知精度が得られるよう に温度センサの設置間隔を決定することが必要となる。

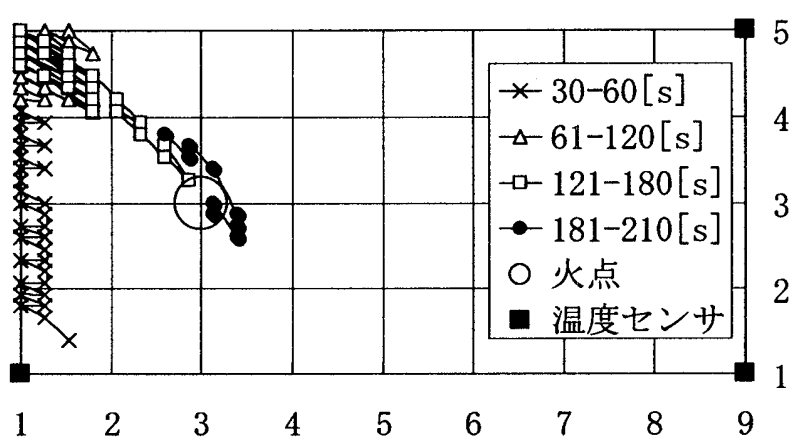

図 123 点の温度センサから火点を推定した結果 (火皿径 $0.4 \mathrm{~m}, H_{f c}=2.81 \mathrm{~m}$, 温度平均時間 $30 \mathrm{~s}$ )

\section{3 温度センサ個数と検知精度の関係}

実験条件（No.2）や温度平均時間（30 秒）は図 12 と同じである が, 座標 $(1,1),(9,1),(9,5)$ に加えて $(1,5)$ の 4 点の温度センサからの温 度情報を基に火点を推定した結果を図 13 に示す。なお，4つの温度 情報を用いて火点検知する場合は，式(12)の右辺に 3 番目と 4 番目 の温度センサから得られる温度および位置情報から算出される項を 加え，残差 $R$ を下式により算出した。

$$
\begin{aligned}
R\left(x_{s}, y_{s}\right)= & \left|\frac{\Delta T_{1}}{\Delta T_{2}}-\left\{\frac{\sqrt{\left(x_{1}-x_{s}\right)^{2}+\left(y_{1}-y_{s}\right)^{2}}}{\sqrt{\left(x_{2}-x_{s}\right)^{2}+\left(y_{2}-y_{s}\right)^{2}}}\right\}^{\gamma}\right| \\
& +\left|\frac{\Delta T_{2}}{\Delta T_{3}}-\left\{\frac{\sqrt{\left(x_{2}-x_{s}\right)^{2}+\left(y_{2}-y_{s}\right)^{2}}}{\sqrt{\left(x_{3}-x_{s}\right)^{2}+\left(y_{3}-y_{s}\right)^{2}}}\right\}^{\gamma}\right| \\
& +\left|\frac{\Delta T_{3}}{\Delta T_{4}}-\left\{\frac{\sqrt{\left(x_{3}-x_{s}\right)^{2}+\left(y_{3}-y_{s}\right)^{2}}}{\sqrt{\left(x_{4}-x_{s}\right)^{2}+\left(y_{4}-y_{s}\right)^{2}}}\right\}^{\gamma}\right|
\end{aligned}
$$

図 13 より，4つの温度センサを用いて検知する場合（以後，4点 検知と言う。）は，3 つの温度センサを用いて検知する場合（以後, 3 点検知と言う。）と比較して検知精度が大幅に向上していることが 分かる。特に, 3 点検知では精度の悪かった 60〜180 秒で顕著な改 善が見られる。なお，30〜60秒の検知精度が悪いのは, 図 5 に示し

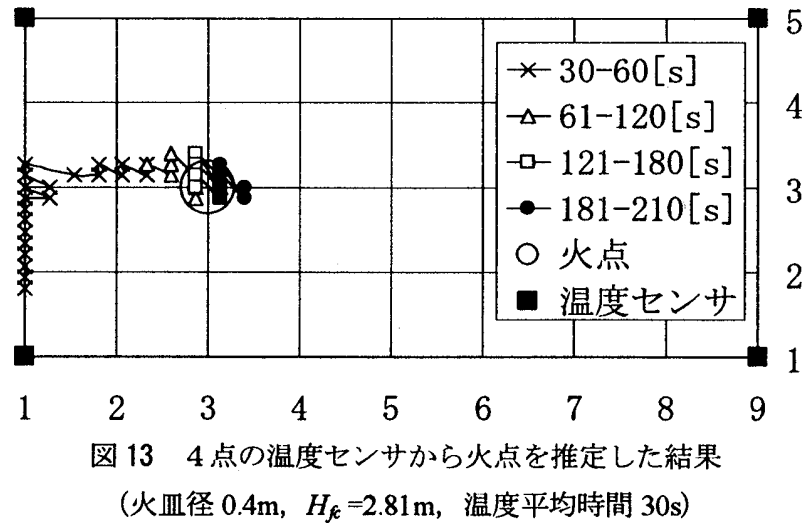




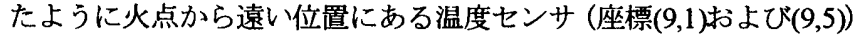
への天井流の到着遅れが主な原因と考えられる。

図14は, 表1に示す全ての実験条件に対して3点検知と4点検知のそ れぞれの場合の平均誤差の算出結果である。なお，3点検知は座標

$(1,1) ，(9,1) お よ ひ ゙(9,5)$ の温度情報を，4点検知は座標 $(1,1) ，(9,1)$,

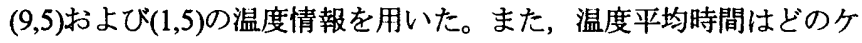
一スも30秒である。

図14より，火血下端から天井までの高さが $0.94 \mathrm{~m}$ のケース(No.10 〜12)では温度センサ個数を変化させても精度向上が見られないも のの, 他のケースでは平均誤差が $1 / 2 \sim 1 / 3$ 程度となり, 検知精度の 大幅な向上が見られる。これより高い検知精度が必要とされる場合 は4点以上の温度情報を用いて検知することが必要と言える。なお, 火血下端から天井までの高さが $0.94 \mathrm{~m}$ のケースにおいて 3 点検知と 4 点検知との結果に大きな違いが見られなかった原因については，次 の5.4火皿下端から天井までの高さと検知精度の関係にて説明する。

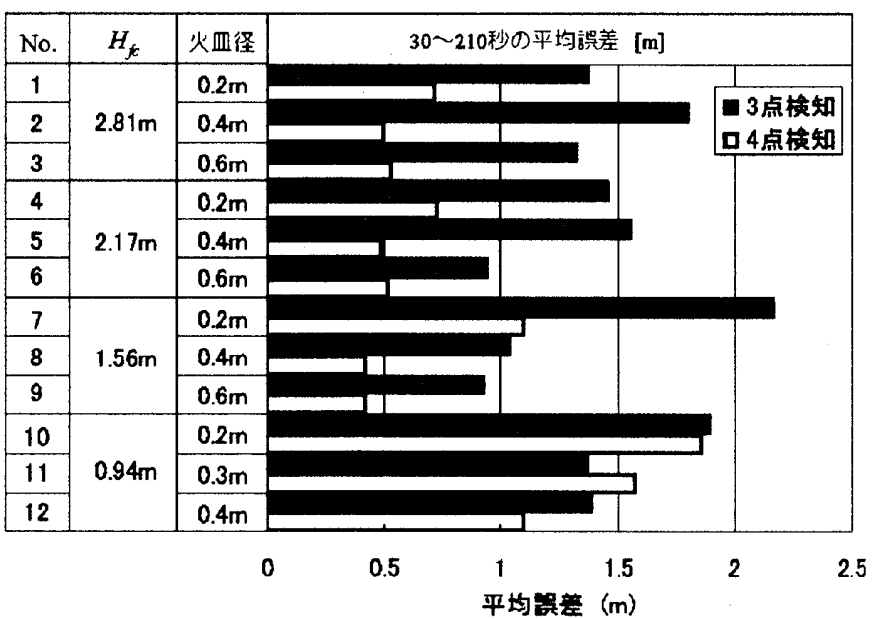

図 14 温度センサ個数と平均誤差(30〜210秒)の関係

\section{4 火血下端から天井までの高さと検知精度の関係}

先に示した図14において, 火皿下端から天井までの高さ $H_{f c}$ と検 知精度の関係に着目すると, 4点検知の場合, 火皿下端から天井まで の高さが $1.56 \mathrm{~m}, 2.17 \mathrm{~m}$ および $2.81 \mathrm{~m}$ の条件下では火皿下端から天井 までの高さと検知精度との間に相関は見られないが，火皿下端から 天井までの高さが $0.94 \mathrm{~m}$ の場合は他の場合と比較して検知精度が極 端に悪くなっている。これは火皿下端から天井までの高さが $0.94 \mathrm{~m}$ の場合, 火点 $(3,3)$ から遠い位置にある温度センサ $(9,1)$ (もしくは $(9,5)$ ）の無次元流動距離が $r / H_{\dot{k}}=6.7$ となっており, 検知手法の基と なる式(14)の適用範囲（0.36 $\leq r / H_{f c} \leq 5.0 ）$ を超えていることが 要因と考えられる。一方, 3点検知の場合は火血下端から天井までの 高さに対する検知精度の依存性は見られない。これは，検知手法の 適用籍囲を超えることに対する誤差よりも天井流の流動距離に対す る減衰率が完全な同心円状にならない (図6参照)ことに起因する誤 差が大きく影響していると思われる。以上より，火点検知は4点検知 を基本とし，さらに温度減衰式の適用範囲および天井高さに応じて 温度センサの設置間隔を見直すことが必要といえる。

\section{5 火源規模と検知精度の関係}

図 14 において，火源規模と検知精度の関係に着目すると，4点検 知の場合, 火皿直径が $0.2 \mathrm{~m}$ から $0.4 \mathrm{~m}$ （もしくは $0.3 \mathrm{~m}$ ）に変化して も検知精度の向上が見られるが, 火源直径が $0.4 \mathrm{~m}$ から $0.6 \mathrm{~m}$ に変化 しても検知精度に有意な差は確認できない。一方，3 点検知では火 皿下端から天井までの高さが $1.56 \mathrm{~m}$ の場合に火四直径が $0.2 \mathrm{~m}$ から $0.4 \mathrm{~m}$ に変化したとき検知精度の向上が見られるものの，他の火血下 端から天井までの高さにおいては火皿直径による検知精度の変化は あまり見られない。

以上より，4 点検知の場合においては火血直径 $0.2 \mathrm{~m}(8.3 \mathrm{~kW})$ の ように火源発熱速度が小さいと検知精度が幾分覀くなる傾向がある が，ある程度以上の火源発熱速度（本実験結果では $40 \mathrm{~kW}$ 以上）に おいては，火源発熱速度に対する依存性は小さいと考えられる。

\section{6. 火源発熱速度の推定}

\section{1 火源発熱速度の推定方法}

火点が特定できると，任意の温度センサ $i$ から得られた温度 $\Delta T_{i}$ と火点と温度センサまでの流動距離 $r_{i}$ を用いて, 原理的には式(14) を火源発熱速度 $\dot{Q}_{f}$ について解いた式(17)から火源の発熱速度を推 定することができる。

$$
\dot{Q}_{f}=\left(\frac{\Delta T_{i}}{k H_{f c}^{(0.81-5 / 3)} r_{i}^{-0.81}}\right)^{3 / 2}
$$

ここで, $k$ 怆

$$
k=\frac{2.03 T_{\infty}}{\left(C_{p} \rho_{\infty} T_{\infty} g^{1 / 2}\right)^{2 / 3}}
$$

で表される比例定数である。これに，雾囲気温度 $T_{\infty}(=293 \mathrm{~K})$ ，雾 囲気密度 $\rho_{\infty}\left(=1.2 \mathrm{~kg} / \mathrm{m}^{3}\right)$, 定圧比熱 $C_{p}(=1.0 \mathrm{~kJ} /(\mathrm{kg} \cdot \mathrm{K}))$ および重 力加速度 $g\left(=9.8 \mathrm{~m} / \mathrm{s}^{2}\right)$ を代入すると，

$$
k=5.6\left[\mathrm{~m}^{5 / 3} \mathrm{~K} / \mathrm{kW}^{2 / 3}\right]
$$

を得る。

温度上昇 $\Delta T_{i}$ は，複数の温度センサのうちの 1 つを選択し，その 温度センサから得られる值を使用する。また流動距離 $\boldsymbol{r}_{i}$ は, 選択し た温度センサ $i$ の設置座標 $\left(x_{i} y_{i}\right)$ と火点検知の結果より得られた火点 座標 $\left(x_{f} y_{f}\right)$ から,

$$
r_{i}=\sqrt{\left(x_{i}-x_{f}\right)^{2}+\left(y_{i}-y_{f}\right)^{2}}
$$

により算出する。

ここで, 式(17)における $H_{f}$ は火皿下端から天井までの高さである。 本研究で提案した火点㭘知手法では火点位置を推定することができ るが火四下端から天井までの高さを知ることはできない。しかし， 火血下端から天井までの高さ $H_{f}$ の代わりに床面から天井までの高 さ $H_{c}$ を採れば火源発熱速度を大きめに見積もることになるため, 結 果としては安全側の推定となる ${ }^{\text {牲4) }}$

\section{2 火源発熱速度の推定結果}

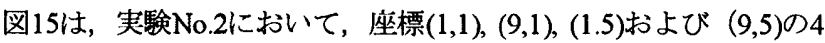
つの温度センサから1秒毎に得られる温度情報を 30 秒間蓄積し，その 30秒間の平均温度を基に火点を推定した結果（図13参照）を使い， 
座標 $(9,5)$ の温度情報を基に火源発熱速度を推定した結果である。な お,ここでは $H_{f_{c}}=H_{c}=2.81 \mathrm{~m}$ とした。

図15より, 300秒以降になると推定值の方が実測值より大きな值を 示しているが，実測值と推定值は良く一致しており，比較的良好な 結果を示していると言える。これより火血下端から天井までの高さ $H_{f c}$ の見積には課題が残るが，火点位直が特定されれば火源発熱速度 を推定することも可能であることが分かる。

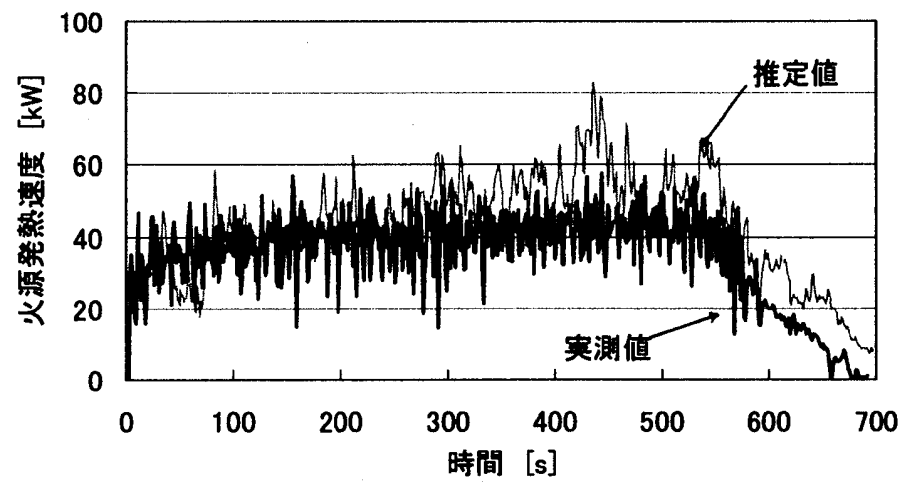

図 15 発熱速度の時間変化

(火血径 $0.4 \mathrm{~m}, H_{f c}=2.81 \mathrm{~m}$, 温度平均時間 $30 \mathrm{~s}$ )

\section{7. まとめと今後の踝題}

天井面下に設置された複数の温度センサから得られる温度情報を 基に火点を検知する手法を開発することを目的として実験的研究を 行った。その結果，以下のような知見が得られた。

(1) 火源発熱速度 $\dot{Q}_{f}$, 火皿下端から天井までの高さ $H_{f c}$ が末知でも 温度センサからの温度情報を基に火点検知を行う手法を提案し た。

（2）温度情報をある一定時間蓄積し，その平均温度を用いると検知 精度が向上する。

(3) 温度センサ数を 3 個から 4 個に増やすことで誤差（実際の火点 位直と検知位置との距離）が約 $1 / 2$ となる。

(4) ある程度の火源発熱速度以上（今回では $40 \mathrm{~kW}$ 以上）において は，火源発熱速度の検知精度に対する依存性は小さい。

(5) 火点検知に用いる $\gamma$ の算出根拠である温度减衰式の適用範囲外 に温度センサが設置されていると,期待する検知精度が得られな い。

(6) 検知された火点座標と温度センサの設置座標ならびにその温度 から火源発熱速度を安全側に推定することができる。ただし，火 皿下端から天井までの高さの影響が大きく, 見積方法にはさらな る検討が必要である。

また今後の課題としては, 成長火源や火源面積が時間的に拡大す るような火災一の適用可能性の検討，側壁，配置物ならびに空調の 吹出気流など天井流性状に影響を与える条件が付加された場合の火 点検知手法の検討が挙げられる。
注

注 1) 温度センサの直下近傍で火炎が発生した場合には当該温度センサがよ どみ領域に入るため，本研究で提案した手法を適用できない。したがっ て, 火点検知に必要な温度センサ個数に 1 を加えた個数の温度センサか らの温度情報を受け取り，最高温度を示す温度センサの情報は使用しな いとするのがよいであろう。

注 2) 一般的な火災感知器から得られる温度情報を基に火点検知する場合, 天 井面に直付けされた火災感知器の感熱部（サーミスタ）は天井下 4〜 $5 \mathrm{~cm}$ の高さに位置する。

注 3) 天井流の温度は天井への失熱, 特に熱伝達率（天井材の種類や厚さ，お よび熱気流速度に応じて決まる実効值）の影響を受ける。しかし，熱伝 達率も時間経過とともに変化するために, どの時間帯の温度を基に算出 するかにより $\gamma$ 值も変動する。今回用いた実験装膡でも, 時間経過とと もに $\gamma$ 值が徐々に上昇する傾向が見られた。但し, 本研究では火災初期 における火点検知を目的としているため， $\gamma$ 值の算出には着火後 200〜 300 秒の時間帯における温度を用いた。

注 4) 火皿下端から天井までの高さ $H_{\boldsymbol{k}}$ と床面から天井までの高さ $H_{c}$ との間に $H_{\boldsymbol{t}}=h H_{c}$ の関係がある場合, $H_{\boldsymbol{t}}$ から算出した火源発熱速度 $\dot{Q}_{f\left(H_{\boldsymbol{k}}\right)}$ と $H_{c}$ から算出した火源発熱速度 $\dot{Q}_{f\left(H_{e}\right)}$ との間には

$$
\frac{\dot{Q}_{f\left(H_{c}\right)}}{\dot{Q}_{f\left(H_{f c}\right)}}=\left\{h^{(0.81-5 / 3)}\right\}^{3 / 2}
$$

の関係がある。したがって火源発熱速度を精度良く推定するためには 火血下端から天井までの高さ $H_{\boldsymbol{c}}$ を正確に見積もる必要がある。

\section{凡例}

$a$ : 適用範囲の下限值 $[-$

$b \quad$ : 適用簀囲の上限値 $[-1$

$C_{p}:$ 空気の比熱 $\left.[\mathrm{J} / \mathrm{kg} \cdot \mathrm{K})\right]$

$d x \quad: x$ 軸方向のグリッド間隔 $[\mathrm{m}]$

$d y: y$ 軸方向のグリッド間隔 $[\mathrm{m}]$

$\bar{E}$ : 平均誤差 $[\mathrm{m}]$

$g:$ 重力加速度 $\left[\mathrm{m} / \mathrm{s}^{2}\right]$

$H$ : 火源から天井までの高さ [m]

$H_{c} \quad:$ 床面から天井までの高さ [m]

$H_{\boldsymbol{f}} \quad:$ 火血下端から天井までの 高さ[m]

h : 床面から天井までの高さ に対する火血下端から天井 までの高さの比[-]

$k$ : 比例定数 $\left[\mathrm{m}^{5 / 3} \mathrm{~K}^{2} \mathrm{~kW}^{2 / 3}\right]$,

m : $y$ 軸方向のグリッド個数[個]

$N$ : 総検知回数[回数]

$\mathrm{n}: x$ 軸方向のグリッド個数[個]

$\dot{Q}_{f}:$ 火源発熱速度 $[\mathrm{kW}]$

$\dot{Q}_{f}\left(H_{c}\right): H_{c}$ から算出した火源 発熱速度 $[\mathrm{kW}]$

$\dot{Q}_{f}\left(H_{f_{c}}\right): H_{\boldsymbol{k}}$ から算出した火源 発熱速度 $[\mathrm{kW}]$

$Q^{*}:$ 無次元発熱速度 $[-]$

$R$ : 残差 $[-]$ $r$ : 火源中心軸からの流動距離

[m]

$T_{\infty}$ : 周囲空気の温度 $[\mathrm{K}]$

$\Delta T$ ：位置 $r$ における天井流の周 囲空気温度からの上昇温度

[K]

$\Delta T_{\mathrm{i}}$ ：温度センサ $i$ の上昇温度 $[\mathrm{K}]$

$\Delta T^{*}$ ：無次元温度上昇[-]

$x_{0}$ : 走查原点の $x$ 座標

$x_{f}$ : 実際の火点中心の $x$ 座標 $x$ 座標

$x_{1} \quad$ : 温度センサ $i$ の $x$ 座標

$x_{s}$ : 走查用の $x$ 座標

$y_{0} \quad$ : 走查原点の $y$ 座標

$y_{f}:$ 実際の火点中心の $y$ 座標

$y_{f(s)}^{\prime}: i$ 回目に検知された火点の $y$ 座標

$y_{1} \quad$ : 温度センサ $i$ の $y$ 座標

$y_{s} \quad$ : 走查用の $y$ 座標

$\boldsymbol{\alpha}$ : 発熱速度のべき乗数 $[-1$

B : 火血下端からの天井高さ のべき乗数 $[-]$

$\gamma \quad$ : 流動距離のべき乗数 $[-]$

$\rho_{\infty} \quad$ : 空気の密度 $\left[\mathrm{kg} / \mathrm{m}^{3}\right]$ $\boldsymbol{x}_{f(s)}^{i}: i$ 回目に検知された火点の

\section{参孝文献}

1) 建筑物の火災安全設計指針，日本建筑学会，2002

2) RL.Alpert : Calculation of Response Time of Ceiling-Mounted Fire Detectors, Fire Technology, Vol.8, p181-194, 1972. 